\title{
New Fauna from Loperot Contributes to the Understanding of Early Miocene Catarrhine Communities
}

\author{
Ari Grossman 1,2, \\ Email agross@midwestern.edu \\ Cynthia Liutkus-Pierce 3
}

Benson Kyongo 4

Francis M'Kirera 5

1 Department of Anatomy, Midwestern

University, Glendale, Arizona, 85308 USA

2 School of Human Evolution and Social Change, Arizona State

University, Tempe, Arizona, 85287 USA

3 Department of Geology, Appalachian State University, Boone, North Carolina, 28608 USA

4 Casting Department, National Museums of Kenya, Nairobi, Kenya

5 Department of Anatomy, Ross University School of Medicine, North Brunswick, New Jersey, 08902 USA

\section{Abstract}

The site of Loperot in West Turkana, Kenya, is usually assigned to the Early Miocene. Recent discoveries at Loperot, including catarrhine primates, led to a revision of its mammalian fauna. Our revision of the fauna at Loperot shows an unusual taxonomic composition of the catarrhine community as well as several other unique mammalian taxa. Loperot shares two non-cercopithecoid catarrhine taxa with Early Miocene 
sites near Lake Victoria, e.g., Songhor and the Hiwegi Formation of Rusinga Island, but Loperot shares a cercopithecoid, Noropithecus, with Buluk (Surgei Plateau, near Lake Chew Bahir). We use Simpson's Faunal Resemblance Index (Simpson's FRI), a cluster analysis, and two partial Mantel tests, to compare Loperot to 10 other localities in East Africa representing several time divisions within the Early and Middle Miocene. Simpson's FRI of mammalian communities indicates that Loperot is most similar in its taxonomic composition to the Hiwegi Formation of Rusinga Island, suggesting a similarity in age $(\geq 18 \mathrm{Ma})$ that implies that Loperot is geographically distant from its contemporaries, i.e., Hiwegi Formation of Rusinga Island, Koru, Songhor, and Napak, while at the same time older than other sites in West Turkana (Kalodirr and Moruorot). The cluster analysis of the similarity indices of all the localities separates Loperot from other Early Miocene sites in the study. Two partial Mantel tests show that both temporal distance and geographic distance between sites significantly influence similarity of the mammalian community among sites. Thus, Loperot's unique location in space and time may explain why it has an unusual catarrhine community and a number of unique taxa not seen elsewhere.

\section{Keywords}

Catarrhine primates

Cluster analysis

Early Miocene

Hiwegi Formation of Rusinga Istand

Loperot

Non-cercopithecoids

Partial Mantel tests

Simpson's Faunal Resemblance Index

\section{Electronic supplementary material}

The online version of this article (doi: 10.1007/s10764-014-9799-8 ) contains supplementary material, which is available to authorized users. 


\section{Introduction}

Cercopithecoidea is a diverse and successful clade that comprises the majority of living catarrhine primate species (Disotell 1996).

Cercopithecoids have a wide geographic distribution over most of the Old World, encompassing a wide latitudinal gradient, and are found in diverse habitats such as tropical and subtropical forests, woodlands, savanna, and grasslands (Jablonski and Frost 2010). By contrast, today, noncercopithecoid catarrhines, represented by modern apes and humans, are relatively taxon poor (Fleagle 19989). This pattern contrasts with the Early Miocene when non-cercopithecoid catarrhines were more taxonomically diverse than cercopithecoids (Fleagle 1998; Jablonski and Frost 2010) even though the two groups apparently began diverging by the Late Oligocene (Stevens et al. 2013). Moreover, although cercopithecoids are clearly well established in Africa by the Early Miocene (Miller et al. 2009), they are usually rare elements in the mammalian community at that time (Jablonski and Frost 2010).

AQ2

Catarrhine paleocommunities during the Early and Middle Miocene of Africa (Table I) occupied a large diversity of habitats and exploited many niches, some quite different from those of modern apes and monkeys (Leakey et al. 2011). Early and Middle Miocene monkeys are usually viewed as members of the Victoriapithecidae, part of Cercopithecoidea, which also includes modern Cercopithecidae (Jablonski and Frost 2010). Recent work (Miller et al. 2009) demonstrates increased diversity within the Victoriapithecidae (the sister family of modern Cercopithecidae). This diversity serves to highlight the complexity of evolutionary history within the Cercopithecoidea. Early to Middle Miocene non-cercopithecoid catarrhines are sometimes viewed as members of the Hominoidea (Michel 2014), or stem-Hominoidea (Stevens et al. 2013). Yet, some authorities prefer to place them in a broader radiation that includes the Dendropithecoidea and Proconsuloidea (Harrison 2010) and exclude most from the Hominoidea. Nevertheless, a broad division exists between cercopithecoid monkeys and the non-cercopithecoid catarrhines. Yet, despite their abundance in Africa during the Early Miocene, we cannot predict when apes and monkeys will be found together at a site, or when only 
one group is more likely to be present.

Table I

African catarrhine paleocommunities used in this study: Age, geographic location, and hi

\begin{tabular}{|c|c|c}
\hline $\begin{array}{c}\text { Site } \\
\text { (coordinates) }\end{array}$ & Age (Ma) & $\begin{array}{r}\text { Non-cercopi } \\
\text { catarrhi }\end{array}$ \\
\hline
\end{tabular}

Early Miocene

Eastern Uganda

Moroto

$\left(2^{\circ} 31^{\prime} 30.0^{\prime \prime} \mathrm{N}, 34^{\circ} 46^{\prime} 21.0^{\prime \prime} \mathrm{E}\right)$

http://en.wikipedia.org/wiki/Mount_Moroto\#cite_note2

\begin{tabular}{|c|c|c|}
\hline $\begin{array}{l}\text { Moroto } \\
\left(2^{\circ} 31^{\prime} 30.0^{\prime \prime} \mathrm{N}, 34^{\circ} 46^{\prime} 21.0^{\prime \prime} \mathrm{E}\right) \\
\text { http://en.wikipedia.org/wiki/Mount_Moroto\#cite_note- } \\
2\end{array}$ & $\begin{array}{l}\text { Aquitanian } \\
\text { (20.6) } \\
\text { (Gebo et } \\
\text { al. 1997; } \\
\text { cf. Pickford } \\
\text { and Mein } \\
2006 \text { for } \\
\text { an } \\
\text { alternative } \\
\text { view) }\end{array}$ & $\begin{array}{l}\text { Afropithecus } \\
\text { turkanensis; } \\
\text { Kogolepithec } \\
\text { morotoensis; } \\
\text { Micropithecu }\end{array}$ \\
\hline $\begin{array}{l}\text { Napak } \\
\left(34^{\circ} 14^{\prime} \mathrm{E} ; 02^{\circ} 05^{\prime} \mathrm{N}\right) \\
(\text { Bishop 1967) }\end{array}$ & $\begin{array}{l}\text { Early } \\
\text { Burdigalian } \\
\text { (18.5-20) } \\
\text { (Pickford } \\
\text { et al. } \\
2010 \text { ) }\end{array}$ & $\begin{array}{l}\text { Proconsul mo } \\
\text { Proconsul af } \\
\text { Dendropithec } \\
\text { macinnesi } \\
\text { Limnopithecr } \\
\text { legetet } \\
\text { Micropithecu } \\
\text { clarki } \\
\text { Lomorupither } \\
\text { harrisoni }\end{array}$ \\
\hline
\end{tabular}

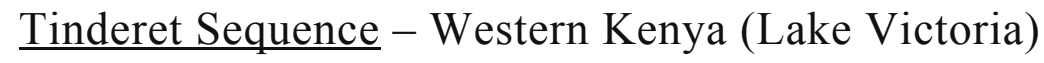

Koru

$35^{\circ} 16^{\prime} \mathrm{E} ; 00^{\circ} 09^{\prime} \mathrm{S}$

(Bishop 1967)
Songhor

35 ${ }^{\circ} 13^{\prime} \mathrm{E} ; 00^{\circ} 02^{\prime} \mathrm{S}$

(Bishop 1967)
Proconsul mo Proconsul afi Dendropithec macinnesi

Limnopithecr legetet Kalepithecus songhorensis Micropithecu clarki

Proconsul mc Dendropithec

19-20; macinnesi

Early

Burdigalian (Bishop et al. 1969)
Rangwapithe gordoni

Limnopithec evansi 


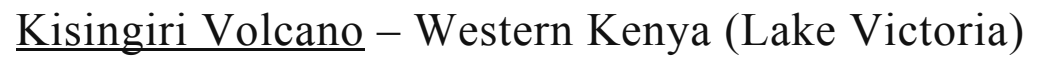

Rusinga - Hiwegi

$00^{\circ} 02^{\prime} \mathrm{S} ; 35^{\circ} 13^{\prime} \mathrm{E}$

(Bishop 1967)
Early

Burdigalian

$(\geq 18 \mathrm{Ma})$

(Peppe et

al. 2011)

Proconsul he Proconsul ny Dendropithec macinnesi

Limnopithecr legetet

Nyanzapithec vancouvering

Late

Rusinga - Kulu

$00^{\circ} 02^{\prime} \mathrm{S} ; 35^{\circ} 13^{\prime} \mathrm{E}$

Burdigalian

(15-17)

(Peppe et

al. 2009)

Proconsul he Proconsul ny Dendropithec macinnesi

\section{Turkana Region}

Loperot

$\left(2^{\circ} 20^{\prime} 0^{\prime \prime} \mathrm{N} ; 35^{\circ} 51^{\prime} 0^{\prime \prime} \mathrm{E}\right)$
Early

Burdigalian

(ca. $19 \mathrm{Ma})$

(this

article)
Limnopithecr legetet Rangwapithe gordoni
Kalodirr

$\left(3^{\circ} 20^{\prime} \mathrm{N}, 35^{\circ} 45^{\prime} \mathrm{E}\right)$

(Boschetto 1988)

\begin{tabular}{|l} 
\\
Moruorot \\
$\left(3^{\circ} 17^{\prime} \mathrm{N}, 35^{\circ} 50^{\prime} \mathrm{E}\right)$ \\
(Boschetto 1988)
\end{tabular}

$\left(3^{\circ} 17^{\prime} \mathrm{N}, 35^{\circ} 50^{\prime} \mathrm{E}\right)$
(Boschetto 1988 )

(Boschetto 1988)
Late

Burdigalian

(16.8-17.5

$\pm 0.3 \mathrm{Ma})$

(Boschetto 1988)

Late

Burdigalian

(16.8-17.5

$\pm 0.3 \mathrm{Ma})$

(Boschetto 1988)
Afropithecus turkanensis Turkanapithe kalakolensis Simiolus enji

Afropithecus turkanensis Turkanapithe kalakolensis Simiolus enji

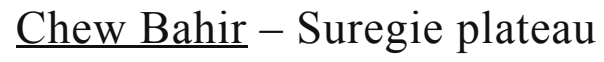


Buluk

$\left(4^{\circ} 16^{\prime} \mathrm{N}, 36^{\circ} 36^{\prime} \mathrm{E}\right)$

(Harris and Watkins 1974)

Late

Burdigalian

$(>17.2)$

Afropithecus

(McDougal

and

Watkins

turkanensis

1985)

\section{$\underline{\text { North Africa }}$}

Wadi Moghara, Egypt

$\left(38^{\circ} 20^{\prime} \mathrm{N}, 28^{\circ} 30^{\prime} \mathrm{E}\right)$

(Approximated from Figure 1.1 in Hasan 2013)

Late

Burdigalian

(17-18)

(Miller

1999)

Early and

Middle

Jebel Zelten, Libya

$\left(28^{\circ} 00^{\prime} \mathrm{N}, 20^{\circ} 30^{\prime} \mathrm{E}\right)$

(Approximate location of Wadi Shatirat in map of

Wessels 2003)

Miocene in

at least

three

distinct

horizons

(Wessels et

al. 2003)

Middle Miocene

Western Kenya - Lake Victoria

Maboko Island

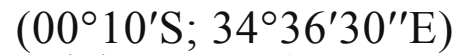

(Bishop 1967)

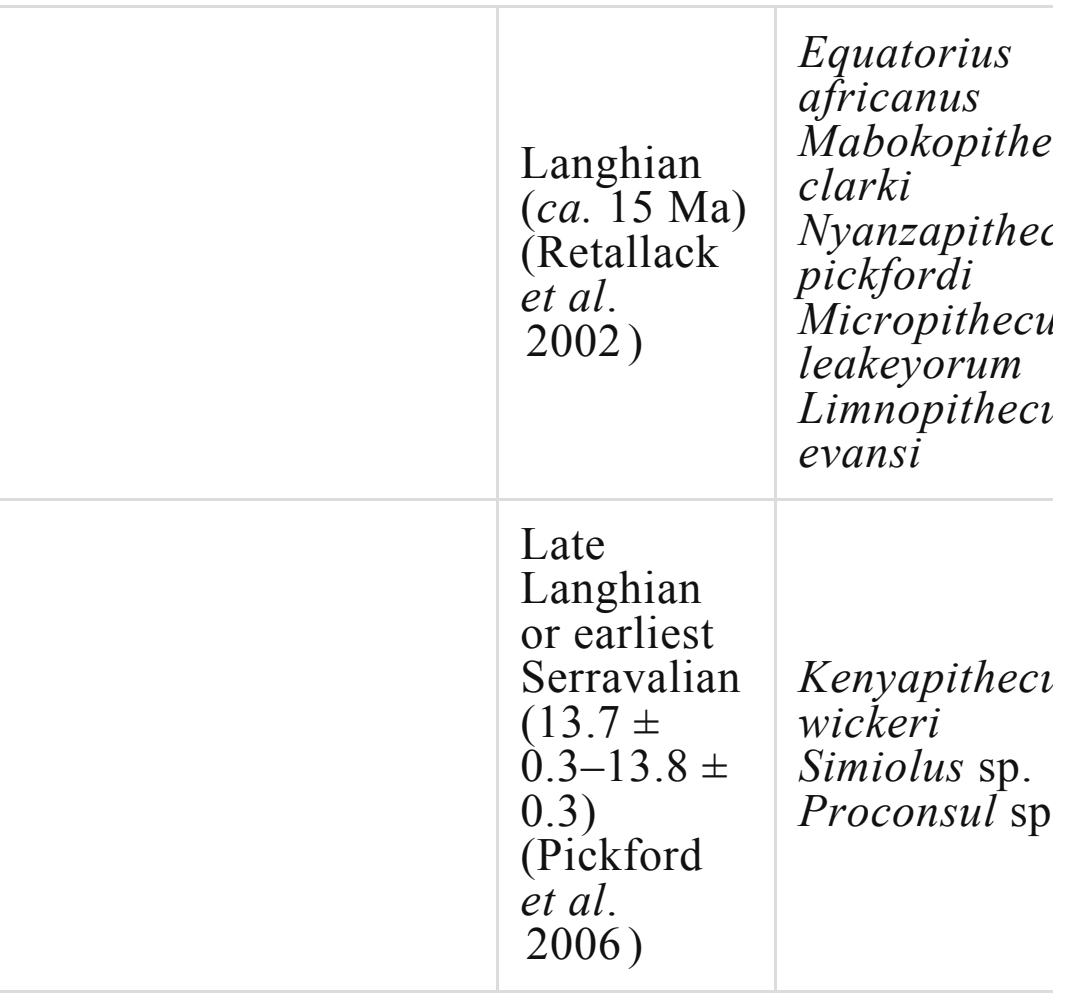

Fort Ternan

$\left(00^{\circ} 13^{\prime} \mathrm{S} ; 35^{\circ} 21^{\prime} \mathrm{E}\right)$

(Bishop 1967)
References for taxonomy: Cote 2008; Drake et al. 1988; Harrison 2010; Leakey et c al. 2009; Patel and Grossman 2006; Peppe et al. 2009; Pickford 2002; as well as pe 
References for habitat reconstructions: Andrews 1992, 1996; Andrews and Van Cou 1976; Andrews et al. 1979, 1981, 1997; Behrensmeyer et al. 2002; Cerling et al. 1 1970; Grossman 2008; Hill et al. 2013; Kappelman 1991; Kortlandt 1983; Leakey Michel et al. 2014; Miller and Wood 2010; Nesbit Evans et al. 1981; Peppe et al. 2 Pickford and Andrews 1981; Pickford and Mein 2006; Pickford et al. 2003; Retalla 2002; Shipman 1986; Shipman et al. 1981; Ungar et al. 2012; Van Couvering and Gautier 1972 .

\section{$\mathrm{AQ3}$}

It is well recognized that community composition is often allied with environmental conditions, so that communities in localities with different habitats, e.g. forests vs. woodlands vs. deserts, will differ in taxonomic composition, species richness, and abundance (Grossman 2008; Kamilar and Beaudrot 2013; Reed 1997). However, recognizing subtle environmental differences among fossil sites is often difficult or unreliable because of factors such as taphonomic biases, lack of abiotic context (geology, sedimentology, etc.) or incomplete samples. Nevertheless, we can test whether other factors, namely temporal differences and geographic distance, significantly affect similarities and differences in the taxonomic composition of the mammalian communities among our study sites. Simply stated, local habitats change over time through numerous local events combined with large-scale climatic and geologic events, all of which lead to effectively change community composition via extinction, speciation, migration, or immigration (Preston 1960). This means we can expect sites that are closest in age to have more similar community composition as long as they are in roughly similar habitats. Similarly, as geographical distance increases, the dispersal propensity of species lessens, possibly because of an increased chance of encountering geographic barriers or unsuitable habitat, which affects the similarity of community composition (Beaudrot and Marshall 2011; Beaudrot et al. 2014; Kamilar 2009; Soininen et al. 2007). Thus, identifying the mammalian communities of Early and Middle Miocene catarrhine-bearing sites and comparing them across time and space will provide important information about the forces that shape the taxonomic composition of early catarrhine communities. 
To address questions about the effects of geographic distance and temporal distance on community composition among Early and Middle Miocene sites we need a sample of sites from different locations over similar time spans. However, Early Miocene catarrhine-bearing sites are unevenly distributed in time and space. Catarrhine-bearing sites of appropriate age are limited to East Africa with a few also in North Africa (including the Arabian Peninsula). This is complicated further by the incompleteness of faunal records for some of the sites. However, one site that can contribute important information to our understanding is Loperot, in West Turkana, in Kenya (Grossman 2013). Our efforts have led to recovery of a number of mammalian taxa, some previously unknown at the site. Among the fossils found are remains of both cercopithecoid and non-cercopithecoid catarrhines. Unlike at most Early Miocene sites, cercopithecoid remains are much more abundant at Loperot than non-cercopithecoids. However, to include Loperot in a comparison among Early and Middle Miocene sites we must first determine its mammalian community and establish its age relative to that of other sites.

Thus, we aim to address the following questions:

1) What is the mammalian community, including the primates, of Loperot, and how does it compare with Early and Middle Miocene sites?

2) What is the age of the mammalian and primate community at Loperot as estimated from faunal comparisons with other Early and Middle Miocene sites?

Once the first two questions are answered we can use this information to address questions about factors affecting the degree of similarity among Early and Middle Miocene mammalian and primate communities in their taxonomic composition. More specifically we ask:

3) Do temporal distance and geographic distance affect the composition of the mammalian communities at catarrhine-bearing localities of the Early and Middle Miocene in Africa? 


\section{Methods}

\section{Description of the Loperot Site}

The fossil-bearing site of Loperot $\left(2^{\circ} 20^{\prime} 0^{\prime \prime}\right.$ North, $35^{\circ} 51^{\prime} 0^{\prime \prime}$ East) is located $90 \mathrm{~km}$ south of the Lothidok range at the headwaters of the Kalabata River, a tributary of the Keno River, which drains south-north to the southwestern shores of Lake Turkana (Fig. 1). This site is found within a larger area $\left(2^{\circ}-\right.$ $2^{\circ} 30^{\prime} \mathrm{N}, 35^{\circ} 30^{\prime}-36^{\circ} \mathrm{E}$ ) with exposed Miocene rocks (Boschetto 1988 ;

Boschetto et al. 1992; Joubert 1966). Previous research at Loperot identified an Early or Middle Miocene fauna that included monkeys and perhaps apes as well as additional mammals (see Table II).

\section{Fig. 1}

Map of Africa showing the location of the sites used in this study. 1) Loperot; 2) Kalodirr and Moruorot; 3) Buluk 4) Moroto; 5) Napak; 6) Rusinga Island; 7) Songhor; 8) Koru; 9) Maboko; 10) Fort Ternan; 11) Wadi Moghara; 12) Gebel Zelten Circles $=$ Early Miocene; Squares $=$ Middle Miocene. 


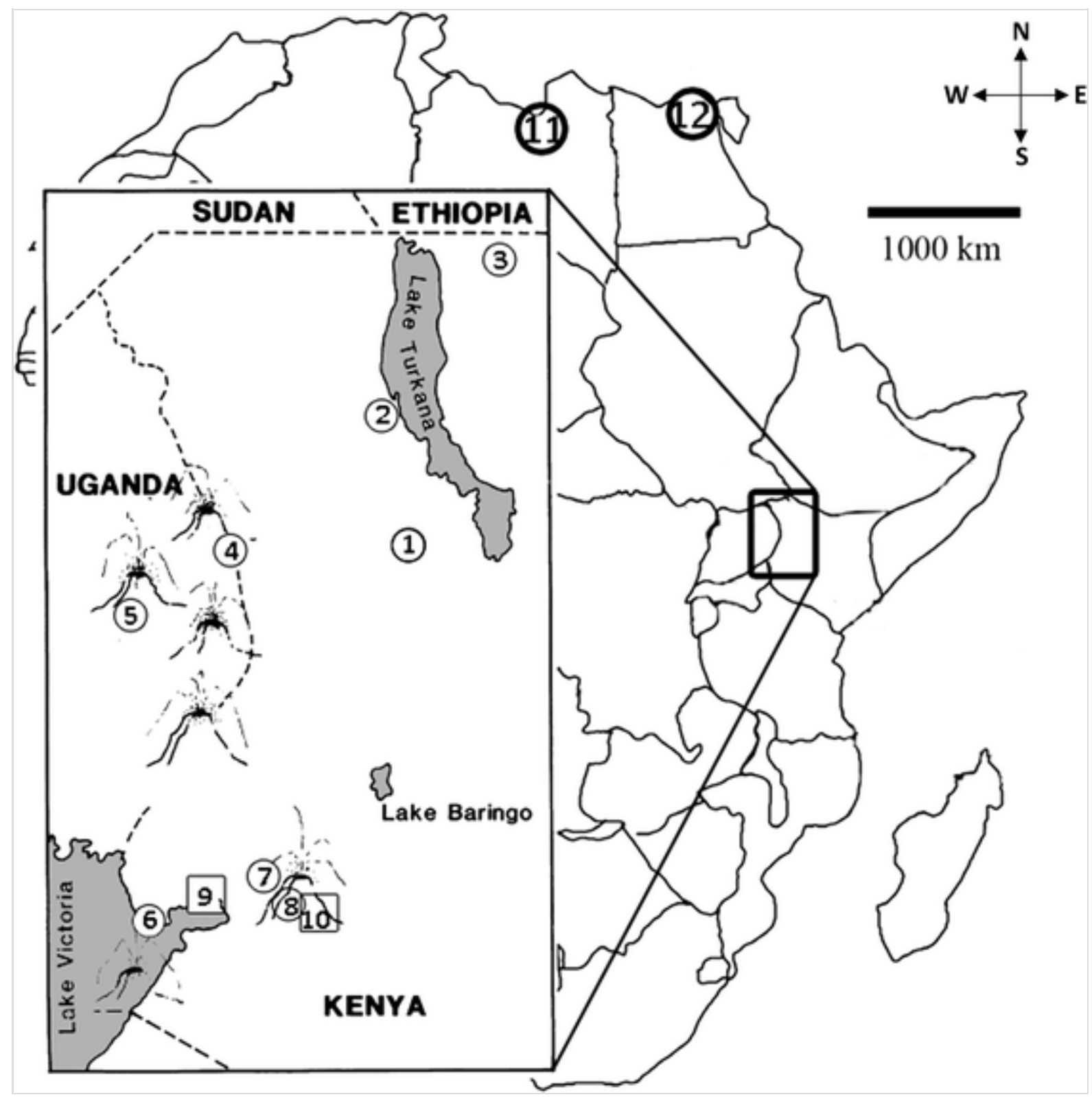

Table II

Taxonomic list of the fauna found in the Early Miocene fossiliferous deposits at Loperot

\begin{tabular}{|l|l|}
\hline \multicolumn{1}{|c|}{ Primates } & \multicolumn{1}{c|}{ indet } \\
\hline Victoripithecidae & Pliohyracidae \\
\hline Noropithecus sp. nov. & cf. Meroehyrax batae \\
\hline Proconsulidae & Perrisodactyla \\
\hline Rangwapithecus gordoni & Rhinocerotidae \\
\hline Family incertae sedis & Chilotheridium pattersoni \\
\hline Limnopithecus legetet $^{\mathrm{a}}$ & cf. Brachypotherium $\mathrm{sp}$. \\
\hline
\end{tabular}




\begin{tabular}{|c|c|}
\hline Rodentia & Artiodactyla \\
\hline Thryonomyidae & Anthracotheriidae \\
\hline Paraphiomys stromeri & Brachyodus aequatorialis \\
\hline Diamantomyidae & Afromeryx cf. zelten $i^{\mathrm{a}}$ \\
\hline Diamantomys leuderzi & Tragulidae \\
\hline Carnivora & Dorcatherium pigotti \\
\hline Felidae & Dorcatherium chappuisi \\
\hline Indet (small) & Giraffidae \\
\hline Creodonta & cf. Canthumeryx syrtensis \\
\hline Hyaenodontidae & Suidae \\
\hline cf. Hyainailouros & cf. Kenyasus rusingensis \\
\hline Indet (Medium-Small species) & Ziphidae \\
\hline Proboscidea & indet \\
\hline \multicolumn{2}{|l|}{ Deinotheriidae } \\
\hline \multicolumn{2}{|l|}{ Prodeinotherium hobleyi } \\
\hline \multicolumn{2}{|l|}{ Gomphotheriidae } \\
\hline \multicolumn{2}{|l|}{ Indet } \\
\hline \multicolumn{2}{|l|}{ Platybelodon sp. ${ }^{\mathrm{a}}$} \\
\hline \multicolumn{2}{|l|}{ cf. Archaeobelodon } \\
\hline \multicolumn{2}{|l|}{ Hyracoidea } \\
\hline \multicolumn{2}{|c|}{ aTaxa published previously but not seen by authors. } \\
\hline \multicolumn{2}{|c|}{$\begin{array}{l}\text { Based on personal observations and the following references: Andrews 1978; } \\
\text { Black 1978; Geraads 2010; Gingerich 2010; Guérin 2000; Harrison 1982, 2010; } \\
\text { Hoojier 1971; Lavocat 1978; Maglio 1969; Mead 1975; Pickford 1991; Sanders } \\
\text { et al. 2010; Savage and Williamson 1978; Simons and Delson 1978. } \\
\text { AQ5 }\end{array}$} \\
\hline
\end{tabular}

In June 2012, we conducted a research expedition to Loperot, identifying four localities (LpM1-LpM4) that yielded numerous vertebrate and invertebrate fossil remains. 


\section{Regional Geologic History of Loperot}

The Lokichar Basin Loperot sits on the western side of modern-day Lake Turkana, a rift lake along the East African Rift System (EARS) situated between the Kenyan and Ethiopian domes (Feibel 2011; Morley et al. 1999a) (Fig. 2). As a result of Tertiary (as well as more recent) faulting, various different basins formed, including the Lokichar Basin, in which the site of Loperot sits (Feibel 2011). The Lokichar Basin is a north-south trending half graben that is $c a .60 \mathrm{~km}$ long by $30 \mathrm{~km}$ wide and is bound by an east-dipping border fault on the west (Morley et al. 1999b). The Lokichar Basin is separated from the neighboring Kerio Basin by a topographic high of gneissic basement (the Lokone Horst) (Hendrie et al. 1994; Morley et al. $1999 \mathrm{~b}$ ). Sediment infill of the Lokichar Basin is on the order of $7 \mathrm{~km}$ and thickens to the west near the border fault (Feibel 2011; Morley et al. 1999b). Analysis of the basin sediments indicates Eocene through Late Miocene strata (Boschetto et al. 1992; Joubert 1966; Morley et al. 1999a).

Fig. 2

Shaded relief map of the southwestern side of Lake Turkana and the location of three of the LpM sites visited in 2012. The sites sit to the west of the Lokone Horst (oblong topographic feature $c a .10 \mathrm{~km}$ to the east of the LpM sites that strikes NE-SW).

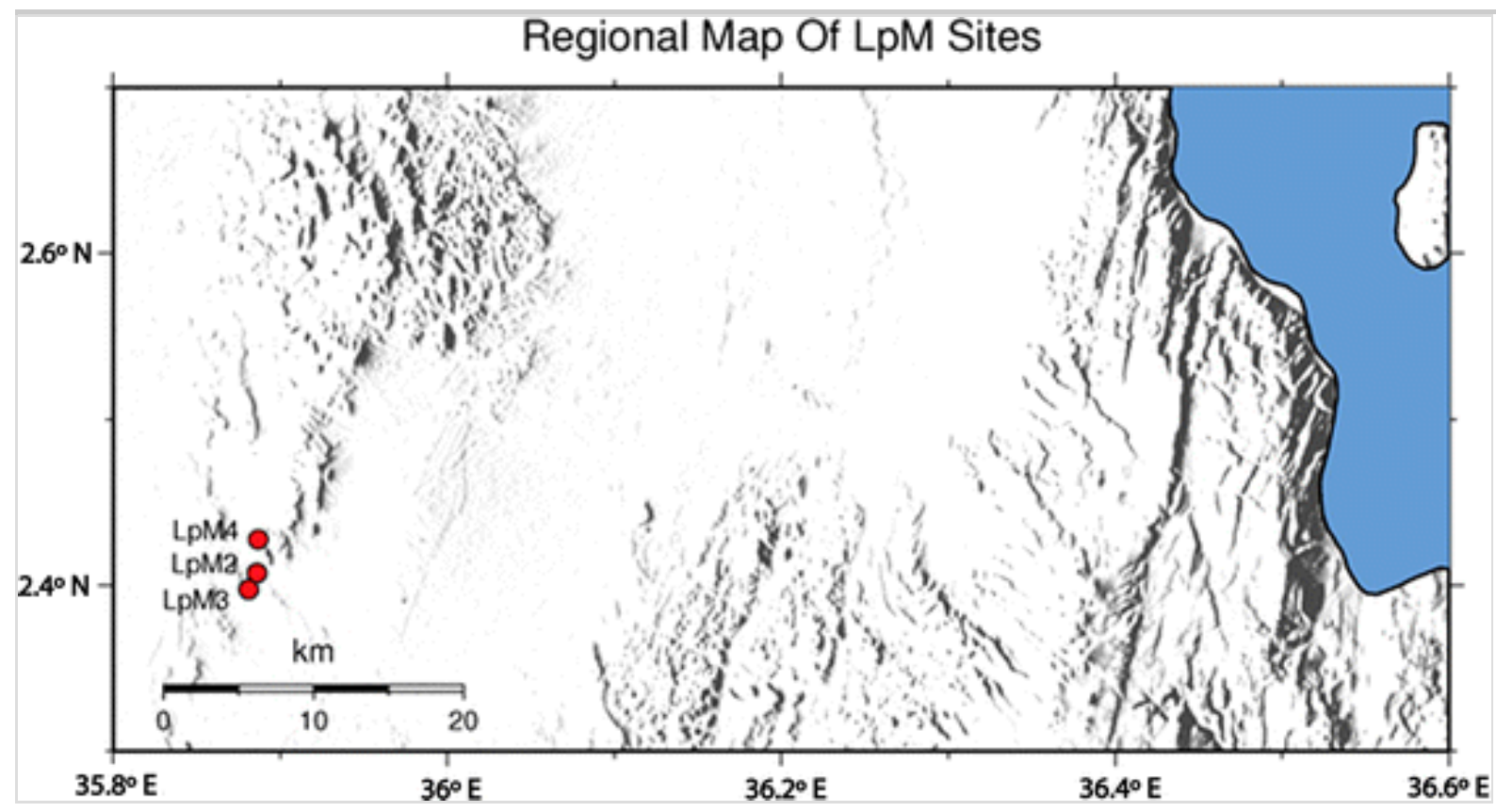




\section{Stratigraphy}

\section{AQ6}

Basin-fill sediments below the Auwerwer Basalts were known previously as the Turkana Grits (Joubert 1966). These sediments are now subdivided into the Lokone and Auwerwer Formations (Morley et al. 1999b). The Lokone Formation (Paleogene-Early Miocene) consists of fluvio-deltaic, arkosic sandstones intercalated with two lacustrine shale units (the older Loperot Shale Member and the younger Lokone Shale Member) (Morley et al. 1999b). Fluvial and lacustrine environments are confirmed by the presence of crocodile, tortoise, oyster, and fish fossils within these sediments (Feibel 2011; Joubert 1966). The Auwerwer Sandstone Formation (Middle Miocene) overlies the Lokone Member, and contains considerable volcaniclastic sediments including reworked tuffs (Morley et al. 1999b). The Auwerwer Basalt directly overlies the Awerwer Sandstone Formation. It is ca. $300 \mathrm{~m}$ thick and gives an age of 12.5-10.7 Ma (Morley et al. 1999b).

\section{Fossil-Bearing Sediments Near Loperot}

Three primary sites (LpM2, LpM3, and LpM4) were identified as potential fossil localities during 2012 fieldwork (Fig. 2), with LpM4 being the most fossiliferous. At LpM4 we were able to find the location where M. Leakey and her team found monkey remains in the past.

\section{Sedimentology and Depositional Environments}

A brief description of the sedimentology at each fossil locality is provided in Table III. The presence of aquatic species, such as crocodiles, fish, and various invertebrates, coupled with the cross-bedding, climbing ripples, and fining-up sequences of the fossil-bearing quartz-rich sand units at all three sites indicate fluvial deposition. Thin, fining-up sequences found at LpM4 suggest shallow, quick (braided) stream flow (with coarse bedload), at least at that site. Red to green silts/sands above and below the fossil-bearing layers represent paleosols, as noted by the ped structure, rhizoconcretions, abundant plant microfossils, and the presence of gypsum and gibbsite. Preliminary identification of pollen grains we found at site LpM4 indicates an abundance of grass (unpublished data). No lacustrine units (dark gray-black shales) were identified at any of the sites. 
Summary of sedimentological features seen in samples from LpM sites, collected in 201\%

\begin{tabular}{|c|c|c|c|c|c|}
\hline Sample & Color & $\begin{array}{c}\text { Grain } \\
\text { size }\end{array}$ & Composition & Texture & Stuctures \\
\hline $\begin{array}{l}\text { LpM2 } \\
\text { Unit } \\
1.1\end{array}$ & $\begin{array}{l}\text { Beige to } \\
\text { yellow }\end{array}$ & $\begin{array}{l}\text { Fine } \\
\text { sand to } \\
\text { silt }\end{array}$ & $\begin{array}{l}\text { Quartz, } \\
\text { feldspar, } \\
\text { calcite, } \\
\text { mafics, mica }\end{array}$ & $\begin{array}{l}\text { Poorly } \\
\text { sorted, } \\
\text { coarse } \\
\text { skewed }\end{array}$ & \\
\hline $\begin{array}{l}\mathrm{LpM} 2 \\
\text { Unit } \\
1.2\end{array}$ & Red & $\begin{array}{l}\text { Medium } \\
\text { to } \\
\text { coarse } \\
\text { sand }\end{array}$ & $\begin{array}{l}\text { Quartz, } \\
\text { calcite, } \\
\text { gibbsite, } \\
\text { mafics, mica }\end{array}$ & $\begin{array}{l}\text { Poorly } \\
\text { sorted }\end{array}$ & $\begin{array}{l}\text { Peds, } \\
\text { rhizoconcentrations, } \\
\text { carbonate nodules }\end{array}$ \\
\hline $\begin{array}{l}\text { LpM3 } \\
\text { Unit } \\
2.1\end{array}$ & Brown & $\begin{array}{l}\text { Medium } \\
\text { to } \\
\text { coarse } \\
\text { sand }\end{array}$ & $\begin{array}{l}\text { Quartz, } \\
\text { minor } \\
\text { feldspar }\end{array}$ & $\begin{array}{l}\text { Poorly } \\
\text { sorted }\end{array}$ & $\begin{array}{l}\text { Contains bone } \\
\text { fragments and } \\
\text { invertebrates }\end{array}$ \\
\hline $\begin{array}{l}\text { LpM3 } \\
\text { Unit } \\
2.2\end{array}$ & $\begin{array}{l}\text { Red/Green } \\
\text { (mottled) }\end{array}$ & $\begin{array}{l}\text { Fine } \\
\text { sand to } \\
\text { silt }\end{array}$ & $\begin{array}{l}\text { Quartz, } \\
\text { feldspar, } \\
\text { calcite, } \\
\text { gibbsite }\end{array}$ & $\begin{array}{l}\text { Poorly } \\
\text { sorted, } \\
\text { coarse } \\
\text { skewed }\end{array}$ & Peds? \\
\hline $\begin{array}{l}\text { LpM3 } \\
\text { Unit } \\
3.1\end{array}$ & Beige & $\begin{array}{l}\text { Medium } \\
\text { to } \\
\text { coarse } \\
\text { sand }\end{array}$ & $\begin{array}{l}\text { Quartz, } \\
\text { feldspar, } \\
\text { mafics }\end{array}$ & $\begin{array}{l}\text { Moderately } \\
\text { sorted }\end{array}$ & Rhizoconcentrations \\
\hline $\begin{array}{l}\text { LpM3 } \\
\text { Unit } \\
3.2\end{array}$ & Red & $\begin{array}{l}\text { Medium } \\
\text { to } \\
\text { coarse } \\
\text { sand }\end{array}$ & $\begin{array}{l}\text { Quartz, } \\
\text { feldspar, } \\
\text { calcite, } \\
\text { mafics, mica }\end{array}$ & $\begin{array}{l}\text { Poorly } \\
\text { sorted, fine } \\
\text { skewed }\end{array}$ & \\
\hline $\begin{array}{l}\text { LpM4 } \\
\text { Unit } \\
4.1\end{array}$ & $\begin{array}{l}\text { Beige to } \\
\text { yellow }\end{array}$ & $\begin{array}{l}\text { Fine to } \\
\text { medium } \\
\text { sand }\end{array}$ & $\begin{array}{l}\text { Quartz, } \\
\text { feldspar, } \\
\text { mafics }\end{array}$ & $\begin{array}{l}\text { Poorly } \\
\text { sorted }\end{array}$ & $\begin{array}{l}\text { Bones, crossbeds, } \\
5-10 \mathrm{~cm} \text { fining up } \\
\text { sequences, grass } \\
\text { pollen }\end{array}$ \\
\hline $\begin{array}{l}\text { LpM4 } \\
\text { Unit } \\
4.2\end{array}$ & Red & $\begin{array}{l}\text { Fine } \\
\text { sand }\end{array}$ & $\begin{array}{l}\text { Quartz, } \\
\text { feldspar, } \\
\text { mica, calcite, } \\
\text { gibbsite, } \\
\text { gypsum }\end{array}$ & $\begin{array}{l}\text { Poorly } \\
\text { sorted }\end{array}$ & $\begin{array}{l}\text { Platy peds, gypsum } \\
\text { crystals, plant } \\
\text { microfossils }\end{array}$ \\
\hline
\end{tabular}

The sedimentology therefore indicates a fluvial depositional environment, suitable (large enough, perennial) to sustain crocodiles, fish, and oysters. Paleosols, however, indicate periods of stability on the land surface, long 
enough for the sediments (likely floodplain silts and fine sands) to alter to soils. It is difficult to know at this time whether the change from a fluvial environment (the quartz sands) to the more stable land surface (paleosols) was due to a climate change, e.g., climate dries and the river ceases to flow, or more simply a change in the river's course, e.g., anastomosing.

\section{Age}

Radiometric age dating of the basalt unit at LpM4 is currently in progress. Even so, the fossil-bearing units at all three primary sites are quartz- and feldspar-rich sands (arkosic composition). This suggests that they belong to the Lokone Formation and are Paleogene-Early Miocene in age (Morley et al. 1999b). Baker et al. (1971) provide an age range of 18.0-16.2 Ma for basalts at Loperot. Hooijer (1971) provides a radiometric age date of $18.0 \pm$ $0.9 \mathrm{Ma}$ on a lava situated stratigraphically higher, e.g., younger, than rhinoceros fossils at a Loperot location $<2 \mathrm{~km}$ from the LpM3 site. However, Mead (1975) provides an approximate age of 17.1 Ma for Loperot. Boschetto et al. (1992) provide age determinations of $13.9 \pm 0.2 \mathrm{Ma}$ and $15.0 \pm 0.2 \mathrm{Ma}$ for Loperot but argue that these dates are too young because of Argon loss in their samples. These reports, coupled with radiometric age dates of tuffaceous strata to the north, led Brown and McDougall (2011) to suggest that mammalian fossils found at Loperot are Early Miocene, while refraining from constraining Loperot within a specific time range.

Following our fieldwork at Loperot, we compiled a revised faunal list (Table II). This list includes our discoveries of taxa previously unknown from Loperot combined with reanalysis of previously published materials. To compare the Loperot material to other sites in East Africa (Fig. 1), we compare the mammalian assemblage of Loperot with the faunal assemblage of 10 other fossil sites (see Electronic Supplementary Material Table SI).

\section{Age Determination for Loperot Using Simpson's Faunal Resemblance Index}

We use Simpson's Faunal Resemblance Index (FRI) to compare among all localities that have a taxonomically sufficient faunal list (Table IV). Simpson's FRI is defined as: FRI $(\%)=(\mathrm{Nc} / \mathrm{N} 1) \times 100$, where $\mathrm{Nc}$ is the number of identified taxa shared by two faunas, and N1 is the number of 
identified taxa in the smaller of the two faunas (Simpson 1960). Simpson's FRI conservatively measures the similarity among two assemblages by simultaneously minimizing the use of samples of uneven size, and is very common in paleontological research (Holroyd and Ciochon 1994; Miller 1999; Nakaya 1994; Tsubamoto et al. 2004). Also, when the taxonomic lists of faunal assemblages at different sites have large differences in size, Simpson's FRI minimizes the effects of this difference (Miller 1999; Tsubamoto et al. 2004). We perform this analysis at the generic level because, typically, genus-level data are more taxonomically stable and robust than species-level data (Alroy 1996; Cifelli 1981; Tsubamoto et al. 2004).

\begin{tabular}{|l||ccccccccccc|}
\hline \multicolumn{1}{|c|}{ Site } & Loperot & Kalodirr & Moruorot & Rusinga-Hiwegi & Rusinga-Kulu & Songhor & Koru & Napak & Moroto & Maboko & Fort Ternan \\
\hline \hline Loperot & 19 & 42.1 & 42.1 & 63.2 & 36.8 & 36.8 & 21.1 & 47.4 & 26.3 & 15.8 & 31.6 \\
Kalodirt & 8 & 32 & 91.3 & 65.6 & 53.8 & 31.3 & 12.5 & 28.1 & 17.2 & 31.3 & 18.8 \\
Moruorot & 8 & 21 & 23 & 60.9 & 43.5 & 26.1 & 8.7 & 30.4 & 17.4 & 39.1 & 34.8 \\
Rusinga-Hilweg & 12 & 21 & 14 & 68 & 96.2 & 66.7 & 67.6 & 67.9 & 48.3 & 41.9 & 45.7 \\
Rusinga-Kulu & 7 & 14 & 10 & 25 & 26 & 61.5 & 38.5 & 69.2 & 19.2 & 30.8 & 46.2 \\
Songhor & 7 & 10 & 6 & 42 & 16 & 63 & 91.2 & 69.8 & 51.7 & 20.9 & 34.3 \\
Koru & 4 & 4 & 2 & 23 & 10 & 31 & 34 & 73.5 & 34.5 & 26.5 & 23.5 \\
Napak & 9 & 11 & 7 & 36 & 18 & 37 & 25 & 53 & 51.7 & 34.9 & 37.1 \\
Moroto & 5 & 5 & 4 & 14 & 5 & 15 & 10 & 15 & 29 & 24.1 & 24.1 \\
Mabolo & 3 & 10 & 9 & 18 & 8 & 17 & 9 & 15 & 7 & 43 & 45.7 \\
\hline Fort Ternan & 6 & 10 & 8 & 16 & 12 & 12 & 8 & 13 & 7 & 16 & 35 \\
\hline
\end{tabular}

\section{Table IV}

Results of the Simpson's Faunal Resemblance Index examining faunal resemblance at the genus level among a set of Early and Middle Miocene sites

\section{Testing the Significance of Geographic Distance and Temporal Distance in Explaining Taxonomic Composition Differences Among Sites}

\section{Cluster Analysis}

We use a hierarchical Unpaired Group Mean Average (UPGMA) cluster analysis (Rohlf 1970) to determine whether the sites in our analysis form discrete groups. We performed the analysis by converting our similarity matrix of 11 sites to a dissimilarity matrix ( 1 - FRI) using the genus-level 
FRI values. We performed this analysis using the SPSS statistics package (IBM release 2009).

\section{Partial Mantel Tests}

We performed two partial Mantel tests (Mantel 1967; Ossi and Kamilar 2006; Smouse et al. 1986) using the Vegan package (Oksanen et al. 2013) for R (R Core Team 2014) to examine the relative importance of temporal distance and geographic distance between sites. Age estimates and location data are provided in Table I. The first partial Mantel test looked at the correlation between taxonomic distance (converting the FRI values to dissimilarity matrix 1 - FRI) and temporal distance while controlling for geographic distance. The second looked at the correlation between taxonomic distance and geographic distance while controlling for temporal distance.

\section{Taphonomic and Collection Biases}

Taphonomic and collecting biases affect the species composition of fossil assemblages as well as the resulting perceived structure of the community. We include in our study only fossil assemblages that include mammals of all size classes and where we cannot a priori identify particular biases that would require exclusion of these sites from the analysis. Therefore, we exclude the Early Miocene sites of Buluk, Wadi Moghara, and Gebel Zelten, from this analysis even though these important sites preserve fossil monkeys. Buluk (Anemone et al. 2005) and Wadi Moghara (Miller 1999) have no rodents or other micromammals published. This biases the composition of the assemblages sufficiently to exclude these sites from the Simson's FRI analysis. Gebel Zelten preserves a large number of micromammals that indicate the assemblage is a time-average of at least four different time zones (Wessels et al. 2003 ), making it unusable. We exclude an important Middle Miocene catarrhine-bearing site, Kipsaramon, from our analysis. Although a small number of recently published specimens from Kipsaramon assigned to Victoriapithecidae genus et species indet. are from sediments estimated to be 15.83-15.59 Ma (Gilbert et al. 2010), most of the cercopithecoid materials described from Kipsaramon were assigned to cf. Noropithecus (Miller et al. 2009 ) and are assigned an approximate age of $c a$. 14.5 Ma (Pickford and Kunimatsu, 2005) further confounding the issue. At present it is unclear whether these two different articles represent parts of a single primate 
community or several different ones. In addition, fauna from Kipsaramon are not fully described limiting utility of the site for our analysis.

\section{Results}

We present the revised list of taxa found at Loperot (Table II) as a single fauna even though the new fossils we discovered in 2012 are from four different loci within the larger Loperot site and other fossils may be from slightly different localities. We feel confident that they form a single assemblage because there is substantial overlap between the fauna found at most localities. Overall, the fauna from Loperot are primarily taxa that are known elsewhere in the Early Miocene of East Africa. Still, as mentioned previously, some taxa are known only from Loperot.

Overall, Loperot is most similar to the Hiwegi Formation of Rusinga Island (Table IV; FRI = 63.2). Next, Loperot is most similar to Napak (FRI = 47.4). Following that, Loperot is most similar to Kalodirr and Moruorot, the other two sites in West Turkana.

The Early and Middle Miocene are separate clusters (Fig. 3 ). The Early Miocene cluster is split into two distinct clusters. One cluster includes Loperot, Kalodirr, and Moruorot. The second includes all the other Early Miocene sites in our study. In the first cluster, Loperot is quite distantly linked to a distinct cluster that includes Kalodirr and Moruorot. In the second Early Miocene cluster, the two Rusinga assemblages form a distinct cluster, as do Koru and Songhor. Napak is nestled in a cluster with Koru and Songhor. Moroto is distantly linked to all the sites in the second cluster. The Middle Miocene sites, although forming a distinct cluster, are not closely linked either.

\section{Fig. 3}

A dendrogram showing the results of an tsing Unpaired Group Mean Average (UPGMA) cluster analysis of the 1-FRI dissimilarity matrix for sites used in the FRI analysis. $\mathrm{LP}=$ Loperot; $\mathrm{WK}=$ Kalodirr; $\mathrm{MO}=$ Moruorot; $\mathrm{RU}-\mathrm{H}=$ RusingaHiwegi Fm.; RU-K=Rusinga-Kulu Fm., SO=Songhor; $\mathrm{KO}=\mathrm{Koru}$; NP=Napak; $\mathrm{MR}=$ Moroto; $\mathrm{MB}=$ Maboko; FT=Fort Ternan. 


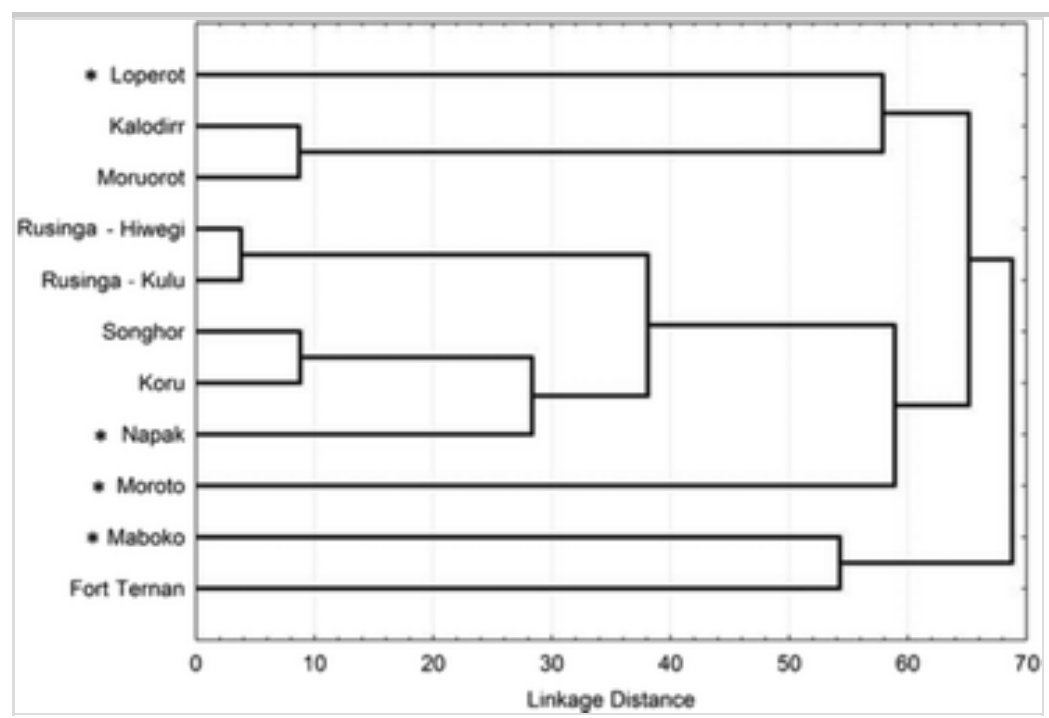

In the first partial Mantel test there is a significant correlation between taxonomic distance and temporal distance while controlling for geographic distance (Mantel statistic $r: 0.5468 ; P=0.001$ ). In the second partial Mantel test there is a significant correlation between taxonomic distance and geographic distance while controlling for temporal distance (Mantel statistic $r: 0.3105 ; P=0.022)$.

\section{Discussion}

\section{Age of Loperot as Indicated by the Fauna}

As demonstrated by the Simpson's FRI, Loperot's best match (FRI $=63.2)$ is to the Hiwegi Formation of Rusinga Island (Rusinga-Hiwegi in Table IV). The Rusinga-Hiwegi fauna is the largest and many other sites also have FRI values in the 60-70 range with Rusinga, e.g., Kalodirr, Moruorot, Songhor, Koru, and Napak. This could suggest that the Rusinga-Hiwegi faunal assemblage may skew the results of this analysis. However, Kalodirr and Moruorot are most similar to each other $(F R I=91.3)$, Songhor and Koru are most similar to each other $(F R I=91.2)$, and Napak is also most similar to Koru $(\mathrm{FRI}=73.5)$. In fact, only Loperot and Rusinga-Kulu are most similar to Rusinga-Hiwegi. However, Loperot and Rusinga-Kulu are not very similar (FRI = 36.8). Therefore, it is unlikely that the Hiwegi Formation fauna from Rusinga dominates the FRI analysis enough to hide real patterns in the data.

The results of the FRI analysis support the placement of Loperot in the Early 
Miocene rather than the Middle Miocene, in accordance with Brown and McDougall (2011). Until recently, the Hiwegi Formation of Rusinga was dated to 17.8 Ma (Drake et al. 1988). Peppe et al. (2011) provide new information that suggests that the Hiwegi Formation is in fact older $(\geq 18.0$ Ma based on text and Fig. 2 of Michel et al. 2014) than previously thought, but still not as old as Songhor and Koru (ca. 19.6 Ma; Bishop et al. 1969; Hill et al. 2013 ) and Napak (ca. 19.6; Bishop et al. 1969; Senut et al. 2000). The latter sites may be age equivalent with the older Wayando Formation of Rusinga Island and Mfangano (Peppe et al. 2011).

It is therefore intriguing that Loperot shares two taxa with Songhor to the exclusion of Rusinga-Hiwegi or any other sites. The primates at Loperot include Rangwapithecus gordoni, previously only known from Songhor (Hill et al. 2013 ) and the nearby and age-equivalent Lower Kapurtay locality (Cote et al. 2014). Both sites are within the Kapurtay Agglomerates Formation of the Tinderet Sequence (Pickford and Andrews 1981), and all the fauna found at Lower Kapurtay are also known from Songhor (Cote et al. 2014). Finding Rangwapithecus gordoni at Loperot is a remarkable range extension for this species. The other taxon that Loperot shares only with Songhor is a proboscidean d4 (KNM-LP 53749: cf. Archaeobelodon in Table II) that is almost identical to KNM-SO 1237 from Songhor. Both these specimen are more primitive than any amebelodontine proboscideans currently known from Rusinga-Hiwegi. This is evident by such features as thinner enamel, lack of posterior accessory cuspules, and relatively small size. Both of these taxa suggest that Loperot may be older than RusingaHiwegi, although more data are needed to test this idea. At Loperot, there are no taxa currently recognized that indicate an age younger than $18 \mathrm{Ma}$, which is in agreement with the fauna and the radiometric ages published by Hooijer (1971). Therefore, we estimate the age of Loperot as older than $18 \mathrm{Ma}$ and perhaps closer to $19 \mathrm{Ma}$.

Effects of Temporal Distance and Geographic Distance on Community Composition

Although a cursory look at the dendrogram presented in Fig. 3 may suggest a regional grouping pattern, this may be true only for sites that are very close geographically, i.e., the Rusinga sites from two different formations, Koru 
and Songhor, and Kalodirr and Moruorot. Even though Napak is geographically closest to Moroto, Napak is nestled in a cluster with Songhor and Koru, and then within a larger cluster that includes the Rusinga localities. Both Moroto and Loperot are linked only distantly to the other sites in the study. In fact, looking at the sites in Turkana and the sites from Uganda, it appears that temporal distance is more likely to explain the distances in linkage between sites from different times. Our estimates for Loperot indicate that it is older than Kalodirr and Moruorot, while Moroto is older than Napak. Napak actually clusters closer to contemporaneous localities (Songhor and Koru) that are geographically more distant than Moroto.

Given the results of the cluster analysis, combined with the unusual primate community and unique fauna at Loperot, we wanted to determine what factors are of primary importance in determining the composition mammalian community of Early Miocene sites. Habitat reconstructions for Loperot are quite preliminary, so we examined two other factors that may contribute to determining the similarity in the composition of mammalian communities: temporal distance and geographical distance. The partial Mantel tests indicate that both time and geographic location have an effect on taxonomic distance. However, at least in our data, temporal differences are more important. Therefore, we divide the Early Miocene sites in our study into three subperiods to allow for more detailed examination. Moroto is the only site within the Aquitanian (23.03-20.44 Ma; Cohen et al. 2013). We can divide the Burdigalian (20.44-15.97 Ma; Cohen et al. 2013) into Early Burdigalian ( $\geq c a$. $18 \mathrm{Ma}$; Rusinga-Hiwegi, Napak, Koru, Songhor, and Loperot) and Late Burdigalian (ca. $18 \mathrm{Ma}-15.97 \mathrm{Ma}$; Kalodirr, Moruorot, Rusinga-Kulu). Maboko and Fort Ternan are both Middle Miocene sites but interestingly represent the two ends of the Langhian (15.97-13.82 Ma; Cohen et al. 2013).

Moroto is the oldest site and is indeed quite separate in its faunal composition from the other Early Miocene localities (highest FRI = 51.7 with Napak and Songhor). Koru, Songhor, and Napak are contemporaneous (ca. 19.5 Ma, Bishop 1969) and indeed we can see how they form a distinct group in the cluster analysis (Fig. 3 ). Within this cluster we see that Napak, geographically more distant, is also separate from a cluster that includes only Koru and Songhor. 
Given the greater correlation and significance of temporal distance we expected Rusinga-Hiwegi and Loperot to cluster together and nestle within a larger cluster of early Burdigalian sites, while we expected Rusinga-Kulu to cluster with Kalodirr and Moruorot in a Late Burdigalian cluster. Indeed, Moruorot and Kalodirr cluster together, but the two Rusinga assemblages and Loperot do not cluster as expected. The faunas of the Hiwegi Formation and the Kulu Formation are very similar, as evidenced by their low linkage distance (Fig. 3), while Loperot is almost as distant from Kalodirr and Moruorot as Moroto is distant from the two Rusinga assemblages (see Fig. 3 ).

Comparing the two Rusinga assemblages, only one genus, Turkanatherium acutirostratum, is reportedly present at Kulu (Peppe et al. 2009) but is not present in the Hiwegi assemblage. However, Geraads (2010) argues that Turkanatherium acutirostratum cannot be identified anywhere but Moruorot (he had no access to the Kalodirr fossils at that time), which would then make the two Rusinga assemblages identical at the genus level. The similarities among the two sites may be a result of sampling size (Kulu $=26$ genera; Hiwegi $=68$ genera), but may also be the result of historically treating the many localities at Rusinga Island as a single time-averaged fauna (Michel et al. 2014). It seems unlikely that two faunal assemblages a million or more years apart (Peppe et al. 2009, 2011) will be identical and perhaps there is a need for reanalysis of the Rusinga faunas, especially given the importance of these localities to understanding of the Early Miocene, as demonstrated by Michel et al. (2014).

The small size of the Loperot assemblage (19 genera) may affect the analysis. However, despite being most similar to Rusinga-Hiwegi in its FRI analysis $(\mathrm{SI}=63.2)$, Loperot does not cluster closely to Rusinga-Hiwegi or any other sites. It is only distantly clustered with other sites in Turkana. Although Loperot is most similar to Rusinga-Hiwegi, other sites such as Rusinga-Kulu $(\mathrm{SI}=96.2)$, Songhor $(\mathrm{SI}=66.7)$, and others are even more similar to Rusinga-Hiwegi. This affects the cluster analysis and provides a likely explanation to why Loperot is not close to Rusinga-Hiwegi in the cluster analysis. Loperot clustering with Kalodirr and Moruorot is likely also the result of other sites being more similar to each other and not any indication of 
much similarity among the West Turkana sites. This is reflected in the very large linkage distance of Loeprot from Kalodirr/Moruorot. Loperot differs from other early Burdigalian sites in its geographic location and from other sites in West Turkana by its age. As both temporal differences and geographic differences affect faunal composition, Loperot's linkage distance on the cluster analysis from the rest of the Early Miocene sites may very well be a real phenomenon resulting from its unique interaction of geography and time.

\section{Composition of Catarrhine Communities in Space and Time}

Loperot shares its non-cercopithecoid catarrhines with Early Burdigalian sites (Songhor, Rusinga-Hiwegi, Koru, and Napak) rather than Late Burdigalian sites (Kalodirr, Moruorot, and Hiwegi-Kulu), even though Kalodirr and Moruorot are geographically closer to Loperot than any other sites. This is in accordance with the greater influence of temporal difference on mammalian community structure indicated by the partial Mantel tests. More importantly, this strongly suggests that the Afropithecus-Turkanapihtecus-Simiolus catarrhine community present in other younger Early Miocene sites in Lake Turkana (Leakey et al. 2011 ) very likely replaced a catarrhine community that primarily comprised taxa shared with other older sites also found in other regions.

In addition to the cercopithecoid specimens at Loperot, a single upper molar from Napak (either M1 or M2), UMP 62-21, was described (although not illustrated) with damaged mesial and buccal margins but intact cusps (Pilbeam and Walker 1968). A frontal was published together with the tooth but has since been assigned to Micropithecus clarki (Fleagle and Simons 1978 ). It is possible that reanalysis of the molar may remove it from the Cercopithecoidea as well. At Moroto, a right lower canine and the lower p3 and 4 of a single individual were assigned to Prohylobates macinnesi (Pickford et al. 2003). A recent revision by Miller et al (2009) erected a number of new genera and species and placed this specimen in Victoriapithecus macinnesi. The cercopithecoid remains from Moroto would also benefit from reexamination, particularly given the large temporal gap between Moroto and Maboko. Although Loperot may share the presence of 
cercopithecoids with Moroto, at present these differ generically and the two sites do not share any non-cercopithecoid catarrhine taxa.

$\mathrm{AQ8}$

Cercopithecoids in our studied sites do not follow the results of the partial Mantel tests. Loperot does not share Noropithecus sp. with any of the sites in the study. However, monkeys are known from three Late Burdigalian sites that we excluded from the study owing to taphonomic biases: Buluk (16.4 \pm 0.2-17.4 \pm 1.6 Ma: McDougal and Watkins 2006), Wadi Moghara (17-18 Ma: Miller 1999), and Gebel Zelten 18-15 Ma (Wessels et al. 2003). The only catarrhines currently known from the North African sites, Wadi Moghara and Gebel Zelten, are cercopithecoids, Prohylobates tandyi and Zaltanpihtecus simonsi respectively (Miller et al. 2009), different from Noropithecus sp. from Loperot. Interestingly, Noropithecus was erected for the cercopithecoid found at Buluk (Miller et al. 2009). Noropithecus differs from all other cercopithecoids in having more bunodont lower molar cusps, and greater degree of molar flare due to mesial and distal cusp tips being more closely approximated (Miller et al. 2009). A formal description of the Loperot cercopithecoid material is outside the scope of this article and is the subject of an ongoing study; still, we place the monkey from Loperot in the genus Noropithecus, albeit a different species than $N$. bulukensis from Buluk (see Table I) because it is similar to N. bulukensis in its bunodont lower molar cusps and close approximation of mesial and distal cusps, leading to a high degree of molar flare. However, Buluk shares non-cercopithecoid catarrhines with Kalodirr and Moruorot and not Early Burdigalian sites. Two other sites may also have Noropithecus present. Nabwal (<17.2 Ma; Fleagle et al. 1997 ) preserves cf. Noropithecus fleaglei, and Kipsaraman (14.5 Ma; Pickford, 1981 ) preserves cf. N. kipsaramanensis (Miller et al. 2009; Pickford and Kunimatsu 2005). Whether these are two species of Noropithecus or not, they are apparently part of a "Noropihtecus" group. Loperot may well represent the oldest member of this group. $\mathrm{AQ} 9$

During the Middle Miocene Victoriapithecus macinnesi is very well known at Maboko, (Benefit 1999), but is not present at Fort Ternan. Miller et al. (2009) recognize Victoriapithecus macinnesi at three Early Miocene sites: Napak, Moroto, in Uganda, and Loperot in Kenya, and several Middle 
Miocene sites: Maboko Island, Majiwa, Nachola, Nyakach, Ngorora, and Ombo, all in Kenya. As mentioned previously, we reassign the material from Loperot to Noropithecus sp., and argue that the very minimal material from Moroto (one canine and two premolars from a single individual), and single incomplete upper molar from Napak, require reanalysis. Therefore, we suggest that it is currently best to treat Victoriapithecus macinnesi as a Middle Miocene taxon only. It is important to note that Noropithecus may have survived into the Middle Miocene as cf. N. kipsaramenssis.

At present it is difficult to evaluate why some sites preserve monkeys along with apes, whereas most preserve only one or the other. In the case of the two North African sites, one can postulate some barrier to the migration of noncercopithecoids, as only cercopithecoids are identified in North Africa or the Arabian Peninsula before the early Middle Miocene when Heliopithecus is found at Ad-Dabtia in Saudi Arabia (Andrews and Martin 1987; Andrews et al. 1978; Harrison 2010). However, no such barrier has been demonstrated.

Temporal differences account for much of the difference in community composition between sites. Loperot shares non-cercopithecoids with the similar-age Hiwegi fauna of Rusinga (Michel et al. 2004) and with maybe even older Songhor and Lower Kapurtay (Cote et al. 2014). The presence of a monkey at Loperot may be the result of geographical differences in the distribution of monkeys, perhaps also suggested by the lack of any monkeys in any sites near Lake Victoria. However, such an idea would require a much greater sampling of catarrhine habitats than is currently available. The differences between the catarrhine communities of the Early Burdigalian and Late Burdigalian sites in East Africa are in agreement with the combined effect of both temporal difference and geographical difference.

\section{Conclusions}

Our analyses indicate that both time differences and spatial distance affect the similarity of community composition in Early Miocene sites. Our study shows that catarrhine communities generally follow that pattern. Our results indicate possible turnover in catarrhine communities over time. Our results also indicate that geographic differences also played a role in differentiating mammalian and catarrhine communities. Further studies are necessary to 
determine if Loperot is unusual in some aspects of its ecology or environments to explain why certain taxa and not others are shared among Loperot and other sites, and why it shares taxa with sites that incorporate a large range of time.

\section{Acknowledgments}

Funding for this project was provided by The Leakey Foundation.

Midwestern University and Appalachian State University provided logistical support and additional funds. We thank the guest editors, K. Reed, J. Kamilar, and L. Beaudrot, for the invitation to participate in the symposium that led to this issue. We are grateful to the Kenyan government and National Museums of Kenya for facilitating our research. We are especially grateful to Drs. E. Mbua and F. Manthi for project support. Thanks also to S. Longoria, T. Moru, and J. Ekeno. The people of Loperot deserve our special thanks for their friendship and assistance while in their land. This manuscript benefitted greatly from reviews by $\mathrm{K}$. McNulty and two anonymous reviewers.

\section{Electronic supplementary material}

Below is the link to the electronic supplementary material.

ESM 1

(DOCX $83 \mathrm{~kb})$

\section{References}

Alroy, J. (1996). Constant extinction, constrained diversification, and uncoordinated stasis in North American mammals. Palaeogeography, Palaeoclimatology, Palaeoecology, 127(1), 285-311.

Andrews, P. (1978). A revision of the Miocene Hominoidea of East Africa. Bulletin of the British Museum of Natural History (Geology), 30, 85-224.

Andrews, P. (1992). Community evolution in forest habitats. Journal of 
Human Evolution, 22, 423-438.

Andrews, P. (1996). Palaeoecology and hominoid Paleoenvironments. Biological Reviews of the Cambridge Philosophical Society, 71, 257-300.

Andrews, P., Begun, D. R., \& Zylstra, M. (1997). Interrelationships between functional morphology and paleoenvironments in Miocene hominoids. In D. R. Begun, C. V. Ward, \& M. D. Rose (Eds.), Function, phylogeny, and fossils: Miocene hominoid evolution and adaptations (pp. 29-57). New York: Plenum Press.

Andrews, P., Hamilton, W. R., \& Whybrow, P. J. (1978). Dryopithecines from the Miocene of Saudi Arabia. Nature, 274, 249-251.

Andrews, P., Lord, J. M., \& Nesbit Evans, E. M. (1979). Patterns of ecological diversity in fossil and modern mammalian faunas. Biologica Journal of the Linnean Society, 11, 177-205.

Andrews, P. J., \& Martin, L. (1987). The phyletic position of the Ad Dabtiyah hominoid. Bulletin of the British Museum of Natural History (Geology), 41, 383-393.

Andrews, P., Meyer, G. E., Pilbeam, D. R., Van Couvering, J. A., \& Van Couvering, J. A. H. (1981). The Miocene fossil beds of Maboko Island, Kenya: Geology, age, taphonomy and palaentology. Journal of Human Evolution, 10, 35-48.

Andrews, P., \& Van Couvering, J. A. H. (1975). Palaeoenvironments in the East African Miocene. In F. S. Szalay (Ed.), Approaches to primate paleobiology (pp. 62-103). Basel: Karger.

Andrews, P., \& Walker, A. (1976). The primate and other fauna from Fort Ternan, Kenya. In G. L. Isaac \& E. R. McCown (Eds.), Human origins: Louis Leakey and the East African evidence (pp. 279-306). Menlo Park, CA: W. A. Benjamin.

Anemone, R. L., Grossman, A., Miller, E. R., \& Watkins, R. T. (2005). 
Biochronology and paleoecology of the Buluk fauna, Early Miocene of northern Kenya. Journal of Vertebrate Paleontology, 25(S3), 32A.

Baker, B. H., Williams, L. A. J., Miller, J. A., \& Fitch, F. J. (1971).

Sequence and geochronology of the Kenya rift volcanics. Tectonophysics, $11,191-215$.

Beaudrot, L., Kamilar, J. M., Marshall, A. J., \& Reed, K. E. (2014). African primate assemblages exhibit a latitudinal gradient in dispersal limitation. International Journal of Primatology DOI.10.1007/s10764014-9773-5

AQ10

Beaudrot, L., \& Marshall, A. J. (2011). Primate communities are structured more by dispersal limitation than by niches. Journal of Animal Ecology, 80, 332-341.

Behrensmeyer, A. K., Deino, A. L., Hill, A., Kingston, J. D., \& Saunders, J. J. (2002). Geology and geochronology of the Middle Miocene Kipsaramon site complex, Muruyur Beds, Tugen Hills, Kenya. Journal of Human Evolution, 42, 11-38.

Benefit, B. R. (1999). Victoriapithecus: The key to Old World monkey and catarrhine origins. Evolutionary Anthropology, 7, 155-174.

Bishop, W. W. (1967). The later Tertiary in East Africa-volcanics, sediments, and faunal inventory. In W. W. Bishop \& J. D. Clark (Eds.), Background to evolution in Africa (pp. 31-56). Chicago: University of Chicago Press.

Bishop, W. W., Miller, J. A., \& Fitch, F. W. (1969). New potassium-argon age determinations relevant to the Miocene fossil mammal sequence in East Africa. American Journal of Science, 267, 669-699.

Black, C. C. (1978). Anthracotheridae. In V. M. Maglio \& H. B. S. Cooke (Eds.), Evolution of African mammals (pp. 423-434). Cambridge, MA: Harvard University Press. 
Boschetto, H. B. (1988). Geology of the Lothidok Range. Master's thesis, University of Utah.

Boschetto, H. B., Brown, F. H., \& McDougall, I. (1992). Stratigraphy of the Lothidok Range, northern Kenya, and K/Ar ages of its Miocene primates. Journal of Human Evolution, 22, 47-71.

Brown, F. H., \& McDougall, I. (2011). Geochronology of the Turkana depression of northern Kenya and southern Ethiopia. Evolutionary Anthropology, 20, 217-227.

Cerling, T. E., Harris, J. M., Ambrose, S. H., Leakey, M. G., \& Solounias, N. (1997). Dietary and environmental reconstruction with stable isotope analyses of herbivore tooth enamel from the Miocene locality of Fort Ternan, Kenya. Journal of Human Evolution, 33, 635-650.

Cerling, T. E., Kappelman, J., Quade, J., Ambrose, S. H., Sikes, N. E., \& Andrews, P. (1992). Reply to Comment on the paleoenvironment of Kenyapithecus at Fort Ternan. Journal of Human Evolution, 23, 371-377.

Cerling, T. E., Quade, J., Ambrose, S. H., \& Sikes, N. E. (1991). Fossil soils, grasses, and carbon isotopes from Fort Ternan, Kenya: Grassland or woodland? Journal of Human Evolution, 21, 295-306.

Cifelli, R. (1981). Patterns of evolution among the Artiodacyla and Perissodactyla (Mammalia). Evolution, 35, 433-440.

Cohen. K. M., Finney, S. .C, Gibbard, P. L., \& Fan J-X. (2013; updated). The ICS International Chronostratigraphic Chart. Episodes, 36:199204. Eohen, K. M., Finney, S., \& Gibbard, P. L. (2013). Internationat Chronostratigraphic Chart. International Commission on Stratigraphy AQ11

Cote, S. M. (2008). Sampling and ecology in three Early Miocene catarrhine assemblages from East Africa. Ph.D. dissertation, Harvard University. 
Cote, S., Malit, N., \& Nengo, I. (2014). Additional mandibles of Rangwapithecus gordoni, an Early Miocene catarrhine from the Tinderet localities of Western Kenya. American Journal of Physical Anthropology, $153,341-352$.

Disotell, T. R. (1996). The phylogeny of Old World monkeys. Evolutionary Anthropology, 5, 18-24.

Drake, R. E., Vancouvering, J. A., Pickford, M. H., Curtis, G. H., \& Harris, J. A. (1988). New chronology for the Early Miocene faunas of Kisingiri, western Kenya. Journal of the Geological Society, London, 145, 479-491.

Feibel, C. S. (2011). A geologic history of the Turkana Basin. Evolutionary Anthropology, 20, 206-216.

Fleagle JG. 1999. Primate Adaptation and Evolution. San Diego: Academic Press.

$\mathrm{Ft}$

Fleagle, J. G., Bown, T. M., Harris, J. M., Watkins, R. W., \& Leakey, M. G. (1997). Fossil monkeys from northern Kenya. American Journal of Physical Anthropology, S24, 111.

Fleagle, J. G., \& Simons, E. L. (1978). Micropithecus clarki, a small ape from the Miocene of Uganda. American Journal of Physical Anthropology, $49,427-440$.

Gebo, D. L., MacLatchy, L., Kityo, R., Deino, A., Kingston, J., \& Pilbeam, D. (1997). A hominoid genus from the Early Miocene of Uganda. Science, 276, 401-404.

Gentry, A. W. (1970). The Bovidae (Mammalia) of the Fort Ternan fossil 
fauna. Fossil Vertebrates of Africa, 2, 243-323.

Geraads, D. (2010). Rhinocerotidae. In L. Werdelin \& W. J. Sanders (Eds.), Cenozoic mammals of Africa (pp. 675-689). Berkeley: University of California Press.

Gilbert, C. C., Goble, E. D., \& Hill, A. (2010). Miocene Cercopithecoidea from the Tugen Hills, Kenya. Journal of Human Evolution, 59, 465-483.

Gingerich, P. D. (2010). Cetacea. In L. Werdelin \& W. J. Sanders (Eds.), Cenozoic mammals of Africa (pp. 873-899). Berkeley: University of California Press.

AQ12

Grossman, A. (2008). Ecological and morphological diversity in catarrhine primates from the Miocene of Africa. Ph.D. dissertation, Stony Brook: Stony Brook University.

Grossman, A. (2013). Primate paleocommunities in the Early Miocene of Africa: Why are apes and monkeys so rarely found together? American Journal of Physical Anthropology, 150, 138.

Harris, J., \& Watkins, R. T. (1974). New Early Miocene vertebrate locality near Lake Rudolf, Kenya. Nature, 252, 576-577.

Harrison, T. (1982). Small bodied apes from the Miocene of East Africa. Ph.D. dissertation, University College London.

Harrison, T. (2010). Dendropithecoidea, Proconsuloidea, and Hominoidea. In L. Werdelin \& W. J. Sanders (Eds.), Cenozoic mammals of Africa (pp. 429-469). Berkeley: University of California Press.

Hasan, S. M. (2013). Sequence stratigraphy of the Lower Miocene Moghra Formation in the Qattara Depression, North Western Desert, Egypt. New York: Springer Science+Business Media.

Hendrie, D. B., Kusznir, N. J., Morley, C. K., \& Ebinger, C. J. (1994). 
Cenozoic extension in northern Kenya: A quantitative model of rift basin development in the Turkana area. Tectonophysics, 236, 409-438.

Hill, A., Nengo, I. O., \& Rossie, J. B. (2013). A Rangwapithecus gordoni mandible from the Early Miocene site of Songhor, Kenya. Journal of Human Evolution, 65, 490-500.

Holroyd, P. A., \& Ciochon, R. L. (1994). Relative ages of Eocene primatebearing deposits of Asia. In J. G. Fleagle \& R. F. Kay (Eds.), Anthropoid origins (pp. 123-141). New York: Plenum Press.

Hooijer, D. A. (1971). A new rhinoceros from the late Miocene of Loperot, Turkana District, Kenya. Bulletin of the Museum of Comparative Zoology, 142, 339-392.

Jablonski, N., \& Frost, S. (2010). Cercopithecoidea. In L. Werdelin \& W. J. Sanders (Eds.), Cenozoic mammals of Africa (pp. 393-428). Berkeley: University of California Press.

Joubert, P. (1966). Geology of the Loperot area. Degree Sheet 18, SE Quarter. No. 74. Ministry of Natural Resources, Geological Survey of Kenya.

Kamilar, J. M. (2009). Environmental and geographic correlates of the taxonomic structure of primate communities. American Journal of Physical Anthropology, 139, 382-393.

Kamilar, J. M., \& Beaudrot, L. (2013). Understanding primate communities: Recent developments and future directions. Evolutionary Anthropology, 22, 174-185.

Kappelman, J. (1991). The paleoenvironment of Kenyapithecus at Fort Ternan. Journal of Human Evolution, 20, 95-129.

Kortlandt, A. (1983). Facts and fallacies concerning Miocene ape habitats. In R. Ciochon \& R. Corruccini (Eds.), New interpretations of ape and human ancestry (pp. 465-514). New York: Plenum Press. 
Lavocat, R. (1978). Rodentia and Lagomorpha. In V. M. Maglio \& H. B. S. Cooke (Eds.), Evolution of African mammals (pp. 69-89). Cambridge, MA: Harvard University Press.

Leakey, M., Grossman, A., Gutiérrez, M., \& Fleagle, J. G. (2011). Faunal change in the Turkana Basin during the Late Oligocene and Miocene. Evolutionary Anthropology, 20, 238-253.

Madden, C. T. (1972). Miocene mammals, stratigraphy and environment of Muruarot Hill, Kenya. PaleoBios, No. 14.

Maglio, V. J. (1969). A shovel-tusked gomphothere from the Miocene of Kenya. Breviora, 310, 1-10.

Mantel, N. (1967). The detection of disease clustering and a generalized regression approach. Cancer Research, 27, 209-220.

McDougall, I., \& Watkins, R. T. (1985). Age of hominoid-bearing sequence at Buluk, northern Kenya. Nature, 318, 175-178.

McDougall, I., \& Watkins, R. T. (2006) Geochronology of the Nabwal Hills: a record of earliest magmatism in the northern Kenyan Rift Valley. Geological Magazine, 143:25-39.

Mead, J. G. (1975). A fossil beaked whale (Cetacea: Ziphiidae) from the Miocene of Kenya. Journal of Paleontology, 49, 745-751.

Michel, L. A, Peppe, D. J., Lutz, J. A., Driese, S. G., Dunsworth, H. M., Harcourt-Smith, W. E., Horner, W. H., Lehmann, T., Nightingale, S., \& McNulty, K. P. (2014). Remnants of an ancient forest provide ecological context for Early Miocene fossil apes. Nature Communications, 5, doi: 10.1038/ncomms4236.

Miller, E., Benefit, B., McCrossin, M., Plavcan, J., Leakey, M., ElBarkooky, A., Hamdan, M., Abdel Gawad, M., Hassan, S., \& Simons, E. (2009). Systematics of early and middle Miocene Old World monkeys. 
Journal of Human Evolution, 57, 195-211.

Miller, E. R. (1999). Faunal correlation of Wadi Moghara, Egypt: Implications for the age of Prohylobates tandyi. Journal of Human Evolution, 36, 519-533.

Miller, E. R., \& Wood, A. (2010). Paleoenvironmental reconstruction of Buluk, Early Miocene, Kenya. Journal of Vertebrate Paleontology, 30(Supplemental), 135A.

Morley, C. K., Ngenoh, D. K., \& Ego, J. K. (1999a). Introduction to the East African Rift System. In C. K. Morley (Ed.), Geoscience of the Rift Systems-Evolution of East Africa, AAPG Studies in Geology, 44, 1-18.

Morley, C. K., Wescott, W. A., Stone, D. M., Harper, R. M., Wigger, S. T., Day, R. A., \& Karanja, F. M. (1999b). Geology and geophysics of the western Turkana Basins. In C. K. Morley (Ed.), Geoscience of the Rift Systems-Evolution of East Africa. AAPG Studies in Geology, 44, 19-54.

Nakaya, H. (1994). Faunal change of Late Miocene Africa and Eurasia: Mammalian fauna from the Namurungule Formation, Samburu Hills, Northern Kenya. African Study Monographs, 20(Supplementary Issue), 1112.

Nesbit Evans, E. M., Van Couvering, J. A. H., \& Andrews, P. (1981). Paleoecology of Miocene sites in Western Kenya. Journal of Human Evolution, 10, 99-116.

Oksanen, J., Guillaume Blanchet, F., Kindt, R., Legendre, P., Minchin, P. R., O’Hara, R. B., Simpson, G. L., Solymos, P., Henry, M., Stevens, H., \& Wagner, H. (2013). Vegan: Community Ecology Package. R package version 2.0-10. http://CRAN.R-project.org/package=vegan

Ossi, K. M., \& Kamilar, J. M. (2006). Environmental and phylogenetic correlates of Eulemur behavior and ecology (Primates: Lemuridae). Behavioral Ecology and Sociobiology, 61, 53-64. 
Patel, B. A., \& Grossman, A. (2006). Dental metric comparisons of Morotopithecus and Afropithecus: Implications for the validity of the genus Morotopithecus. Journal of Human Evolution, 51, 506-512.

Peppe, D. J., Deino, A. L., Mcnulty, K. P., Lehmann, T., Harcourt-Smith, W. E. H., Dunsworth, H. M., \& Fox, D. L. (2011). New age constraints on the Early Miocene faunas from Rusinga and Mfangano Islands (Lake Victoria, Kenya). American Journal of Physical Anthropology, 144(Supplement 52), 237.

Peppe, D. J., McNulty, K. P., Cote, S. M., Harcourt-Smith, W. E. H., Dunsworth, H. M., \& Vancouvering, J. A. (2009). Stratigraphic interpretation of the Kulu Formation (Early Miocene, Rusinga Island, Kenya) and its implications for primate evolution. Journal of Human Evolution, 56, 447-461.

Pickford, M. (1981). Preliminary Miocene mammalian biostratigraphy for western Kenya. Journal of Human Evolution, 10, 73-97.

Pickford, M. (1983). Sequence and environments of the Lower and Middle Miocene Hominoids of Western Kenya. In R. L. Ciochon \& R. S.

Corruccini (Eds.), New interpretations of ape and human ancestry (pp. 421-439). New York: Plenum Press.

Pickford, M. (1987). Fort Ternan (Kenya) palaeoecology. Journal of Human Evolution, 16, 305-309.

Pickford, M. (1991). Revision of the Neogene Anthracotheriidae of Africa. The Geology of Libya (pp. 1491-1525). Amsterdam: Elsevier.

Pickford, M. (1995). Fossil land snails of East Africa and their palaeoecological significance. Journal of African Earth Sciences, 20, 167226.

Pickford, M. (2002). New reconstruction of the Moroto hominoid snout and a reassessment of its affinities to Afropithecus turkanensis. Human Evolution, 17, 1-19. 
Pickford, M., \& Andrews, P. (1981). The Tinderet Miocene sequence in Kenya. Journal of Human Evolution, 10, 11-33.

Pickford, M., \& Kunimatsu, Y. (2005). Catarrhines from the Middle Miocene (ca. 14.5 Ma) of Kipsaraman, Tugen Hills, Kenya. Anthropological Science, 113, 189-224.

Pickford, M., \& Mein, P. (2006). Early Middle Miocene mammals from Moroto II, Uganda. Beiträge der Paläontologie, 30, 361-386.

Pickford, M., Musalizi, S., Senut, B., Gommery, D., \& Musiime, E. (2010). Small apes from the Early Miocene of Napak, Uganda. Geo-Pal Uganda, 3, 1-110.

Pickford, M., Sawada, Y., Tayama, R., Matsuda, Y.-K., Itaya, T., Hyodo, H., \& Senut, B. (2006). Refinement of the age of the Middle Miocene Fort Ternan Beds, Western Kenya, and its implications for Old World biochronology. Comptes Rendus Geoscience, 338, 545-555.

Pickford, M., Senut, B., Gommery, D., \& Musiime, E. (2003). New catarrhine fossils from Moroto II, early Middle Miocene (ca 17.5 Ma) Uganda. Comptes Rendues Paleoevolution, 2, 649-662.

Pilbeam, D. \& Walker, A. (1968). Fossil Monkeys from Miocene of Napak North-East Uganda. Nature, 220:657.

Preston, F. W. (1960). Time and space and the variation of species. Ecology 41:611-627.

R Core Team. (2014). R: A language and environment for statistical computing. Vienna, Austria: R Foundation for Statistical Computing. http://www.R-project.org/ .

Reed, K. E. (1997). Early hominid evolution and ecological change through the African Plio-Pleistocene. Journal of Human Evolution, 32, 
Retallack, G. J. (1991). Miocene paleosols and ape habitats of Pakistan and Kenya. New York: Oxford University Press.

Retallack, G. J. (1992a). Middle Miocene fossil plants from Fort Ternan (Kenya) and evolution of African grasslands. Paleobiology, 18, 383-400.

Retallack, G. J. (1992b). Comment on the paleoenvironment of

Kenyapithecus at Fort Ternan. Journal of Human Evolution, 23, 363-369.

Retallack, G. J., Wynn, J. G., Benefit, B. R., \& McCrossin, M. L. (2002).

Paleosols and paleoenvironments of the Middle Miocene, Maboko

Formation, Kenya. Journal of Human Evolution, 42, 659-703.

Rohlf, F. J. (1970). Adaptive hierarchical clustering schemes. Systematic Zoology, 19, 58-82.

Sanders, W. J., Gheerbrant, E., Harris, J. M., Saegusa, H., \& Delmer, C. (2010). Proboscidea. In L. Werdelin \& W. J. Sanders (Eds.), Cenozoic mammals of Africa (pp. 161-252). Berkeley: University of California Press.

Savage, R. J. G., \& Williamson, P. G. (1978). The early history of the Turkana Depression. In W. W. Bishop (Ed.), Geological background to fossil man (pp. 375-394). Edinburgh: Scottish Academic Press.

Senut, B., Pickford, M., Gommery, D., \& Kunimatsu, Y. (2000). Un nouveau genre d'Hominoide du Miocene Inferieur d'Afrique Orientale: Ugandapithecus major (Le Gros Clarke \& Leakey, 1950). Comptes Rendues des Academie des Seances, 331, 227-233.

Shipman, P. (1986). Paleoecology of Fort Ternan reconsidered. Journal of Human Evolution, 15, 193-204.

Shipman, P., Walker, A., Van Couvering, J. A., Hooker, P. J., \& Miller, J. A. (1981). The Fort Ternan hominoid site, Kenya: Geology, age, 
taphonomy and paleoecology. Journal of Human Evolution, 10, 49-72.

Simons, E. L., \& Delson, E. (1978). Cercopithecidae and Parapithecidae. In V. M. Maglio \& H. B. S. Cooke (Eds.), Evolution of African mammals (pp. 100-119). Cambridge, MA: Harvard University Press.

Simpson, G. G. (1960). Notes on the measurement of faunal resemblance. American Journal of Science, 258A, 300-311.

Smouse, P., Long, J., \& Sokal, R. R. (1986). Multiple regression and correlation extensions of the Mantel test of matrix correspondence. Systematic Zoology, 35, 627-632.

Soininen, J., McDonald, R., \& Hillebrand, H. (2007). The distance decay of similarity in ecological communities. Ecography, 30, 3-12.

Sokal, R. R., \& Sneath, P. H. A. (1963). Prineiples of numerieat taxomomy. San Franeiseo: W. H. Freeman.

$\mathrm{AQ13}$

SPSS Inc. (Released 2009). PASW Statistics for Windows, Version 18.0. Chicago: SPSS Inc.

Stevens, N. J., Seiffert, E. R., O'Connor, P. M., Roberts, E. M., Schmitz, M. D., Krause, C., Gorscak, E., Ngasala, S., Hieronymus, T. L., \& Temu, J. (2013). Palaeontological evidence for an Oligocene divergence between Old World monkeys and apes. Nature, 497, 611-614.

Tsubamoto, T., Takai, M., \& Egi, N. (2004). Quantitative analyses of biogeography and faunal evolution of Middle to Late Eocene mammals in East Asia. Journal of Vertebrate Paleontology, 24, 657-667.

Ungar, P., Scott, J., Curran, S., Dunsworth, H., Harcourt-Smith, W., Lehmann, T., Manthi, F., \& McNulty, K. (2012). Early Neogene environments in East Africa: Evidence from dental microwear of tragulids. Palaeogeography, Palaeoclimatology, Palaeoecology, 342, 84-96. 
Van Couvering, J. A. H., \& Van Couvering, J. A. (1976). Early Miocene mammal fossils from East Africa: Aspects of geology, faunistics and paleo-ecology. In G. L. Isaac \& E. R. McCown (Eds.), Human origins: Louis Leakey and the East African evidence (pp. 155-208). Menlo Park, CA: W. A. Benjamin.

Van Damme, D., \& Gautier, A. (1972). Some fossil molluscs from Muruarot Hill (Turkana District, Kenya). Journal of Conch, 27, 423-426.

Wessels, W., Fejfar, O., Peláez-Campomanes, P., van der Meulen, A., \& de Bruijn, H. (2003). Miocene small mammals from Jebel Zelten, Libya. Coloquios de Paleontología, Ext., 1, 699-715. 